\title{
FISHERIES AND CLIMATE CHANGE: INEVITABILITY OR PROPHYLAXIS? CONTRIBUTING TO A NECESSARY DEBATE
}

\author{
Pedro Valadas Monteiro
}

Regional Directorate of Agriculture and Fisheries of Algarve and Centre for Marine Technology and Engineering (CENTEC) - IST, University of Lisbon, Portugal

Corresponding Author, Email: jpvmonteiro@gmail.com

\section{ARTICLE INFO}

Received: 7 October 2015

Received in revised form: 16 March 2016

Accepted: 22 April 2016

Available online: 30 May 2016

\begin{abstract}
Climate changes constitute the greatest challenge of this century due to the modifications they cause in weather and environmental conditions, and thus affecting the social and economic dynamics at multiple levels. Because all invertebrates and fish used for human consumption are poikilotherms, they are very sensitive to modifications in the environment, namely temperature and levels of oxygen. Phenomena like temperature rising, acidification, ocean stratification and changes in salinity are already perceptible and susceptible of causing severe consequences in aquatic ecosystems. Falling productivity, species migration and localized extinctions, as well as conflict over the use of scarce resources and increased risks associated with more extreme climatic events are among the possible consequences. Increased climate variability justifies a focus on the design and promotion of strategies to control the inherent risk and increase the resilience of marine and freshwater systems that strongly affect the livelihoods of millions of human beings worldwide. A multidimensional and holistic concept for the sustainable management of maritime and marine resources is indissociable from the unequivocal evidence of climate changes. Raising awareness of public in general and ocean stakeholders for the relevance of the topic at hand are assumed as key dimensions with the present article.
\end{abstract}

Monteiro, P. V. (2016): Fisheries and climate change: Inevitability or prophylaxis? Contributing to a necessary debate. Croatian Journal of Fisheries, 74, 130-140. DOI: 10.1515/cjf-2016-0020.

\section{INTRODUCTION}

It is now widely accepted that climate change is no longer simply a potential threat, it is unavoidable; a consequence of 200 years of excessive greenhouse gas (GHG) emissions from burning fossil fuels, deforestation and industrial agriculture has led to a spike in carbon dioxide levels in the atmosphere resulting not just in rising atmospheric and marine temperatures, but also in ocean acidification (IPCC, 2007a). More precisely, Otto-Bliesner et al. (2015) refer that concentrations of major greenhouse gases were largely stable prior to the late 19th century, with only relatively small variations related to natural feedbacks in the carbon and nitrogen cycles. Major increases in $\mathrm{CO}_{2}, \mathrm{~N}_{2} \mathrm{O}, \mathrm{CH}_{4}$ and $\mathrm{F}_{11 / 12}$ occurred during the 20th century.

The build-up of carbon dioxide and other greenhouse gases in the atmosphere is changing several of the features of the earth's climate, oceans, coasts and freshwaterecosystems, and the physical factors involved include atmospheric circulation, intensity and variability patterns, ocean currents and mixing, stratification, hydrological cycles and seasonal patterns. In response to changing concentrations of $\mathrm{CO}_{2}$ or other forcings, 
the climate system changes in ways that are independent of any global-mean surface temperature change, but that subsequently influence the global-mean radiation budget and, hence, surface temperature (Sherwood et al., 2015). On the other hand, Holmyard (2014) mentions that climate changes are observed in all geographical regions, causing the warming of the atmosphere and oceans, diminishing the extent and volume of snow and ice; sea levels are rising and weather patterns are changing. Sherwood et al. (2015) point out the fact that recent work reveals that heterogeneous responses also occur within the troposphere and can produce similar but more subtle problems. For example, increasing the concentration of $\mathrm{CO}_{2}$ in the atmosphere affects longwave radiative fluxes and slightly warms the middle and lower troposphere, even with no surface temperature change. In general, salinity is increasing in surface ocean waters of the more evaporative regions, while there is a decreasing trend in high latitudes. The combined effect of the temperature and salinity changes due to climate warming would reduce the density of the ocean surface, increase vertical stratification and change surface mixing, but with some geographical differences. Large salinity anomalies have been observed in the past with important ecosystem responses (Cochrane et al., 2009). Atmospheric temperatures are projected to rise by $1.8-4.0^{\circ} \mathrm{C}$ globally and sea levels $0.45-0.82 \mathrm{~m}$ higher than present by 2100 , and even if GHG emissions are stopped immediately, temperatures will remain elevated for centuries due to the effect of greenhouse gases from past human emissions already present in the atmosphere (IPCC, 2007b). Limiting climate change and their dramatic consequences will require substantial and sustained reductions of greenhouse gas emissions, stated the IPPC in 2013 (IPPC, 2014a). To provide a more comprehensive and consistent analysis of predicted extinction risks from climate change, Urban (2015) performed a meta-analysis of 131 published predictions. If climate changes proceed as expected, one in six species could face extinction. Several regions, including South America, Australia and New Zealand, face the greatest risk. To prevent the most severe impacts of climate change, parties to the UN Framework Convention on Climate Change (UNFCCC) agreed a target of keeping the rise in average global temperature since pre-industrial times below $2^{\circ} \mathrm{C}$, and to consider lowering the target to $1.5^{\circ} \mathrm{C}$ in the near future (Holmyard, 2014).

According to Pinnegar (2012), ocean acidification is increasingly being viewed as a major threat to marine ecosystems, and yet the issue only came to public attention less than ten years ago. It consists in the ongoing decrease in the $\mathrm{pH}$ of the earth's oceans. Impacts of climate change and ocean acidification are generally exacerbated by other factors such as overfishing, habitat loss and pollution. The latter, because it exacerbates low dissolvedoxygen concentrations, is contributing to an increase in the number of 'dead zones' in the ocean, as well as to an increase in harmful algal blooms. Oxygen Minimum Zones (OMZs) are naturally present in many habitats including marine sediments, but are also expanding due to anthropogenic influences. Over the past 50 years, open ocean $\mathrm{O}_{2}$ concentrations have decreased by a mean rate of 0.1 to $>0.3 \mu \mathrm{mol}$ per $\mathrm{kg}$ per year (IPPC, 2014b).

Climate change and other anthropological actions are altering aquatic ecosystems in profound ways, with consequent impacts on fisheries and aquaculture: warmer temperatures affect the physiological processes of freshwater and marine fish; the increased risks associated with sea level rise and the occurrence of extreme events - for instance, Marciano, Lackmann and Robinson (2014), when analysing the changes in U.S. East Coast cyclone dynamics related to climate change, predict an increase in future cyclone intensity because of the enhancement of latent heating - could severely impact daily life in fishing communities and various economic activities like fish processing industries and coastal tourism, usually concentrated in coastal or low lying zones. The consequences for the sustainability of fisheries and aquaculture and for the people who depend on them are still uncertain. Some countries and activities will benefit while others will suffer. The same happens with living organisms; Parmesan and Yohe (as cited in Palmer et al., 2015) argue that the limited success of attempts to explain this high interspecific variation implies a fundamental lack of understanding how drivers of change operate and how species respond to these climate changes. According to The WorldFish Center (2007), climate change may affect fisheries and aquaculture directly by influencing fish stocks and the global supply of fish for consumption, or indirectly by influencing fish prices or the cost of goods and services required by fishers and fish farmers, besides the fact that the poorest and most vulnerable will be disproportionately affected by its impacts (IFAD, 2008). While poverty in fishing communities or other forms of marginalization reduces their ability to adapt and respond to change, increasingly globalized fish markets are creating new vulnerabilities to market disruptions which may result from climate change (Cochrane et al., 2009).

For many communities around the world, the disturbance of these marine ecosystems impacts the local residents, both socially and economically. Understanding these linkages between climate change, livelihoods and food security is critical for designing adaptation policies, here understood as the process of adjustment to actual or expected climate and its effects, and management strategies that increase resilience for fisheries and aquaculture in the communities, nations and regions that depend on them, i.e. the capacity of social, economic and environmental systems to cope with a hazardous event or trend or disturbance, responding or reorganizing in ways that maintain their essential function, identity and structure. Doing so effectively will require sustained investment in research that informs policy, resource management and development (The WorldFish Center, 2009).

\section{THE GROWING RELEVANCE OF FISHERIES AND AQUACULTURE WORLDWIDE}

According to FAO, global fisheries and aquaculture production totalled 195.8 million tonnes in 2014 - around 16\% more than in 2010 (Table 1), due to the fact that although marine captures 
appear to be stable (around 90 million tonnes of wild fish captured by a total number of fishing vessels estimated to be about 4.7 million in 2012), aquaculture, that represented more than $51 \%$ of the total production in 2014 , remains one of the fastest-growing food-producing sectors and is set to play a key role in meeting the rising demand for fishery products. The share of fisheries production used for direct human consumption increased from about $70 \%$ in the 1980 s to more than $85 \%$ in 2012.

Global fish production growth continues to outpace world population growth. China is by far the world's largest producer with a declared production of more than 76 million tonnes in 2014, as displayed in Table 2, almost $40 \%$ of the world's total production, representing aquaculture 3.4 times the production of fisheries.

The rapid expansion of aquaculture, including the activities of small-scale farmers, is driving this growth in production and fish farming holds tremendous promise in responding to surging demand for food which is taking place due to global population growth (Ababouch, 2014). According to Table 1, global aquaculture production marked a record high of 101 million tonnes in 2014 (a raise of more than 15,000\% when compared to 1950) valued in USD 166 billion. World aquaculture is heavily dominated by the Asia-Pacific region, which represents $89 \%$ of total production in volume and $77 \%$ in value. Out of curiosity, the Asia-Pacific area accounts for $98 \%$ of the world production of carp, $95 \%$ of the oysters and $88 \%$ of all shrimp. Norway and Chile are the world leaders for salmon farming, respectively $33 \%$ and $31 \%$ of the global production.

With this increasing production and greater availability for consumers, per capita fish consumption continues to rise - from $10 \mathrm{~kg}$ in the 1960s to more than $19 \mathrm{~kg}$ in 2012, according to FAO - driven by higher demand from a growing population, rising incomes and more efficient distribution channels. In the EU-27 the average consumption ranged between $4.2 \mathrm{~kg}$ per capita in Bulgaria and $56 \mathrm{~kg}$ in Portugal, which is more than twice the EU average, representing the third place worldwide, just behind Japan and Iceland.

Fish already accounts for almost $17 \%$ of the global population's intake of protein - in some coastal and island countries it can top 70\% (Ababouch, 2014). Fish remains an ever-important source of energy, protein and a range of essential nutrients. Moreover, fish provided nearly 3 billion people with almost $20 \%$ of their intake of animal protein, and 4.3 billion people with about $15 \%$ of such protein. Protein from fish is a crucial nutritional component in some densely populated countries where total protein intake levels may be low. Consuming fish is particularly important during pregnancy and the first two years of life and can help lower the risk of coronary heart disease mortality.

\section{CLIMATE CHANGE EFFECTS: OUTPUTS AND PROJECTIONS WITH PARTICULAR EMPHASIS ON FISHERIES AND AQUACULTURE}

Global average air temperatures rose by $0.74^{\circ} \mathrm{C}$ in the period 1906-2005 (IPCC, 2007a). According to Cochrane et al. (2009), one should notice that the ocean plays an important role in regulating the climate. Its heat capacity (and thus net heat uptake) is about 1,000 times larger than that of the atmosphere. Warming is not exclusive to surface waters, with

Table 1. World fisheries and aquaculture production

\begin{tabular}{|c|c|c|c|c|c|c|}
\hline \multicolumn{7}{|c|}{ Capture: quantity (t) } \\
\hline \multicolumn{2}{|l|}{ Ocean area } & 2010 & 2011 & 2012 & 2013 & 2014 \\
\hline \multicolumn{2}{|l|}{ Inland waters } & 11264748 & 11099487 & 11606144 & 11708766 & 11898482 \\
\hline \multicolumn{2}{|l|}{ Marine areas } & 78929327 & 83695521 & 80829259 & 82250180 & 82746647 \\
\hline \multicolumn{2}{|l|}{ Total } & 90194075 & 94795008 & 92435403 & 93958946 & 94645129 \\
\hline \multicolumn{7}{|c|}{ Aquaculture: Quantity (t) } \\
\hline Ocean area & Environment & 2010 & 2011 & 2012 & 2013 & 2014 \\
\hline \multirow{2}{*}{ Inland waters } & Brackishwater & 746298 & 802248 & 886326 & 860332 & 912916 \\
\hline & Freshwater & 36236920 & 37840610 & 41241116 & 43992176 & 46277489 \\
\hline \multicolumn{2}{|c|}{ Total Inland waters } & 36983218 & 38642559 & 42127442 & 44852507 & 47190405 \\
\hline \multirow{2}{*}{ Marine areas } & Brackishwater & 4570337 & 5176078 & 5486210 & 6110631 & 6493390 \\
\hline & Marine & 36475447 & 38830703 & 42435473 & 46198907 & 47455277 \\
\hline \multicolumn{2}{|c|}{ Total Marine areas } & 41045784 & 44006781 & 47921682 & 52309538 & 53948667 \\
\hline \multicolumn{2}{|l|}{ Total } & 78029002 & 82649339 & 90049124 & 97162045 & 101139072 \\
\hline \multicolumn{2}{|c|}{$\begin{array}{l}\text { GRAND TOTAL } \\
\text { (capture + aquaculture) }\end{array}$} & 168223077 & 177444347 & 182484527 & 191120991 & 195784201 \\
\hline
\end{tabular}

Source: FAO - Fisheries and Aquaculture Information and Statistics Branch - Downloaded from http://www.fao.org/fishery/statistics/ on 2016/03/22. 
Table 2. China fisheries and aquaculture production

\begin{tabular}{rcccccc}
\hline \hline Capture $(\mathbf{t})$ & Ocean Area & $\mathbf{2 0 1 0}$ & $\mathbf{2 0 1 1}$ & $\mathbf{2 0 1 2}$ & $\mathbf{2 0 1 3}$ & $\mathbf{2 0 1 4}$ \\
\hline & Inland waters & 2289603 & 2232661 & 2298199 & 2309812 & 2297717 \\
& Marine areas & 13371847 & 13810030 & 14126905 & 14248136 & 15054393 \\
Total China & & 15661450 & 16042691 & 16425104 & 16557948 & 17352110 \\
Aquaculture (t) & Ocean Area & $\mathbf{2 0 1 0}$ & $\mathbf{2 0 1 1}$ & $\mathbf{2 0 1 2}$ & $\mathbf{2 0 1 3}$ & $\mathbf{2 0 1 4}$ \\
\hline & Inland waters & 23552712 & 24785076 & 26517693 & 28098250 & 29434768 \\
Total China & Marine areas & 24276897 & 25388063 & 27425231 & 29014925 & 29362490 \\
GRAND TOTAL & & 47829610 & 50173139 & 53942924 & 57113175 & 58797258 \\
(capture + aquaculture) & & 63491060 & 66215830 & 70368028 & 73671123 & 76149368 \\
\hline \hline
\end{tabular}

Source: FAO - Fisheries and Aquaculture Information and Statistics Branch - Downloaded from http://www.fao.org/fishery/statistics/ on $2016 / 03 / 22$.

the Atlantic showing particularly clear signs of deep warming. Global average sea surface temperatures have also risen since 1950 as the ocean has absorbed $80 \%$ of the heat added to the climate system; temperature increases are also being detected as deep as $3000 \mathrm{~m}$. This warming will be accompanied by rising sea temperatures, changing sea levels, increasing ocean acidification, altered rainfall patterns and river flows, and higher incidence of extreme weather events (The WorldFish Center, 2009). Increasing water temperature and associated thermal expansion accounts for $57 \%$ of the global average sea level rise of $1.8 \mathrm{~mm}$ per year between 1961 and 2003; a further $28 \%$ of the rise is attributed to the melting of glaciers and polar ice sheets (IPCC, 2007a). Oceans absorb about a quarter of all carbon dioxide $\left(\mathrm{CO}_{2}\right)$ emitted from the burning of fossil fuels. Plankton converts some of that $\mathrm{CO}_{2}$ into organic matter, part of which is exported into the deeper ocean. The remaining $\mathrm{CO}_{2}$ causes progressive acidification from chemical reactions between $\mathrm{CO}_{2}$ and seawater, acidification being exacerbated by nutrient supply and with the spreading loss of $\mathrm{O}_{2}$ content. These changes all pose risks for marine life and may affect the oceans' ability to perform the wide range of functions that are vitally important for environmental and human health (IPPC, 2014b). Some evidences of such phenomena have already been witnessed:

- The ocean's pH has already fallen by 0.1 in the last 200 years, roughly corresponding to a $30 \%$ increase in acidity. Model estimates predict further reduction of $0.3 \mathrm{pH}$ units by 2100 if $\mathrm{CO}_{2}$ emissions continue to rise at the current rate as the oceans absorb more anthropogenic $\mathrm{CO}_{2}$ (Pinnegar, 2012; Cochrane et al., 2009 and Holmyard, 2014).

- To date average alkalinity has declined from 8.2 to 8.1 , equivalent to a $30 \%$ increase in acidity (IPCC, 2007b).

Pinsky et al. (2013) compiled a database of coastal surveys around North America between 1968 and 2011, sampling 128 million individuals across 360 marine taxa. Climate velocity explained the magnitude and direction of shifts in latitude and depth much more effectively than did species characteristics. Their results demonstrate that marine species shift at different rates and directions because they closely track the complex mosaic of local climate velocities.
Based on current rates of GHG emissions increase, the results of future climate change and current GHG emissions for fisheries and aquaculture are already inducing and/or are likely to provoke:

- The decrease of the $\mathrm{pH}$ affects the value below which calcium carbonate dissolves calcite and aragonite thus reducing the available levels that are used by marine organisms to build their shells, i.e. shellfish cultivation. For some fish species reproduction may be affected once $\mathrm{pH}$ reduces the mobility of male gametes. Furthermore, extreme drought could lead to the extinction of freshwater species. Commercial fin-fishes also may be impacted because of changes in the marine food-web. Larvae and juveniles of most fish are reliant on planktonic crustaceans which may be impacted by future ocean acidification. Fabry et al. (as cited in Pinnegar, 2012) mention the fact that, as adults, many commercial fish species (e.g. haddock and plaice) are also reliant on bivalve molluscs or echinoderms which are predicted to decline in the future as a result of ocean acidification.

- Higher sea temperature is a major cause of coral bleaching and damage to reef ecosystems around the globe (The WorldFish Center, 2007). Nicholls et al. (2007) state that sea temperatures exceeding long-term summer averages by $1^{\circ} \mathrm{C}$ for more than four consecutive weeks make coral reefs suffer 'bleaching', rejecting the colourful algae with which they normally have a symbiotic relationship, resulting in loss of colour, greater exposure to disease and often to death. When this occurs on a global scale it is referred to as a "mass bleaching event". Six such events have occurred since 1979. The "bleaching" event of 1998, driven by El Niño, a global coupled ocean-atmosphere phenomenon that changes the location and timing of ocean currents and causes important inter-annual variability in sea surface temperature, killed an estimated $16 \%$ of the world's coral (The WorldFish Center, 2007).

- Lan et al. (2014) analyzed the long-term (1967-2009) records of grey mullet catch per unit effort (CPUE) in the Taiwan Strait (TS) to investigate the influences of climatic indices on the annual catch of grey mullet at multiple timescales. Grey mullet Mugil cephalus is one of the most important commercial 
species of fish in the coastal fisheries of Taiwan. In this study, it was observed that the fishing grounds of grey mullet have shifted to the north following changes in the $20^{\circ} \mathrm{C}$ isotherm in the TS (the $20^{\circ} \mathrm{C}$ isotherms in the TS in the winter shifted from $23-24^{\circ} \mathrm{N}$ in $1958-1978$ to north of $25^{\circ} \mathrm{N}$ after 1998 ).

- Since all aquatic species that are grown for human consumption are poikilotherms, they are affected directly by changes in temperature and oxygen levels, which have impact on migration, spawning and feeding patterns, distribution and abundance (Holmyard, 2014). Among prominent examples, warming has caused and will cause, with high confidence, according to IPPC (2014b): northward shift and expansion of the geographic distribution of North Atlantic cod and shifting growth patterns in relation to the distribution of Banded morwong around New Zealand; the shift of dominant species from sardines to anchovies in the Sea of Japan; warming extremes have reduced and will further reduce the abundance of eelpout in the Wadden; extreme warming events increase mortalities of Pacific salmon during spawning migrations in the Fraser River, Canada; at temperate and high latitudes, communities display increasing fish species richness resulting from latitudinal shifts of species and attributed to warming and loss of sea ice, although the relative contributions of regional climate variation and long-term global trends have not been quantified; latitudinal species shifts are projected to continue in the 21 st century under all IPCC emission scenarios.

- Concentrations of chlorophyll - an indicator of net primary production - in the North Pacific, Indian and North Atlantic Oceans decreased by about $10 \%$ in the period 1998-2010. This may be due to man-made climate change or to natural variability (Holmyard, 2014).

- Projections of ocean biological response to climate warming by 2050 show contraction of the highly productive marginal sea ice biome by $42 \%$ and $17 \%$ in Northern and Southern Hemispheres, respectively, according to authors like Sarmiento et al., Meehl et al. and Christensen et al. (as cited in Cochrane et al., 2009). The sea ice biome accounts for a large proportion of primary production in polar waters and supports a substantial food web.

- Satellite observations suggest a six percent reduction in global oceanic primary production between the early 1980s and the late 1990s, but with substantial regional differences. For example, chlorophyll in higher latitudes has increased in the last 20 years, followed by a change in the relative dominance of diatoms over small phytoplankton (Cochrane et al., 2009).

- Toresen and Østvedt (as cited in Pinnegar, 2012) argued that the abundance of Norwegian spring spawning herring increased during the warming of the 1920s, decreased during the cooling period in the 1960s but has risen again since the temperature increases of the 1990s.

- In the North Pacific and North Atlantic, range limits of many intertidal species have shifted by up to $50 \mathrm{~km}$ per decade. These rates are generally faster than for species on land and carry the risk that food webs will be seriously disrupted for example, predators moving away from prey (Holmyard, 2014). In the same vein, Sydeman et al. (2015) point out, as main mechanisms of climate change associated with marine vertebrates: (i) direct physiological responses and (ii) climate-mediated predator-prey interactions.

- According to Hanna et al. (2015) recent changes are found in the means and variability of the North Atlantic Oscillation (NAO) index. There has been a sustained significant recent decrease in the summer NAO since the 1990s and, at the same time, a striking increase in variability of the winter NAO - especially December - that resulted in three of five (two of five) record high (record low) NAO Decembers occurring during 2004-2013 in the 115-year record. Sousa Reis et al. (2001) analyzed long-term changes in sardine Sardina pilchardus, bluefin tuna Thunnus thynus and octopus Octopus vulgaris in relation to upwelling, NAO and turbulence indices. They concluded that the intense upwelling can lead to decrease of sardine biomass on the southwestern coast of Portugal. Also Santos et al. (2001) reported a negative impact of upwelling events observed off Portugal during winter months on recruitment of sardine $S$. pilchardu) and horse mackerel Trachurus trachurus. Bluefin tuna dynamics seem to be related with NAO but on the other hand it is likely that an increase in sea surface temperature will considerably change the population response in the Northeastern Atlantic, expecting an enhancement of recruitment and a recovery in bluefin abundance in the next decades. In the octopus case, the rise of sea surface temperature in future can negatively affect the recruitment process (Sousa Reis et al., 2001).

\section{ASSESSING SOME POSSIBLE IMPACTS OF CLIMATE CHANGES ONFISHING AND AQUA- CULTURE-DEPENDENT COMMUNITIES}

According to Burke, Hsiang and Miguel (2015), if future adaptation mimics past adaptation, unmitigated warming is expected to reshape the global economy by reducing average global income roughly by $23 \%$ by the year 2100 and widening global income inequality, relative to scenarios without climate change. In contrast to prior estimates, expected global losses are approximately linear in global mean temperature, with median losses many times larger than leading models indicate. Fish remains among the most traded food commodities worldwide. In 2013, exports of fish and fishery products totalled 36.4 million tonnes and USD 139.1 billion in value as displayed in Table 3 (China alone represented almost $11 \%$ of the worldwide exports). Fish exports lead with a 69\% in quantity and almost $63 \%$ in value.

Trade in fish and fishery products is especially important for developing nations, in some cases worth over half of the total 
value of traded commodities. This means fisheries and fish farming are playing an increasingly critical role for many local economies.

According to Ababouch (2014), some 58.3 million people were engaged in the primary sector of capture fisheries and aquaculture in 2012. Of these, 37 percent were engaged full time. FAO estimates that fisheries and aquaculture support the livelihoods of $10-12 \%$ of the world's population as a vital source of employment and income. Since 1990, employment in the sector has grown at a faster rate than the world's population and in 2012 almost 60 million people were engaged in the primary sector, $90 \%$ small-scale fishers and $15 \%$ of them women (in secondary activities such as processing, this latter figure can be as high as $90 \%$ ). Of these, $84 \%$ were employed in Asia, followed by Africa with about $10 \%$.

Climate change poses a compounding threat and new challenges to the sustainability of fisheries and aquaculture systems. Impacts occur, according to Cochrane et al. (2009), as a result of both gradual warming and associated physical changes as well as from frequency, intensity and location of extreme events, and take place in the context of other global socio-economic pressures on natural resources.

Following projections which could help to anticipate some possible scenarios are presented here:

- Climate change was predicted to lead to losses in gross fisheries revenues worldwide of $\$ 17-41$ billion by 2050 (Pinnegar, 2012). Losses are likely to be highest in East Asia and the Pacific.

- The latest studies predict that fish forced migrations could reduce maximum catch potential in some areas of the tropics by up to $40 \%$ (Cheung et al., 2010), but this figure might be even higher if predicted negative effects of climate change on coral reefs or the impact of ocean acidification are taken into account (Cheung et al., 2009). Mangroves and other coastal vegetation buffer the shore from storm surges that can damage fish ponds and other coastal infrastructure and may become more frequent and intense under climate change. Mean sea level is predicted to rise between 10 and 90 centimeters during this century, with most predictions in the range of 30-50 centimeters. In some areas reduced precipitation could lead to reduced run-off from land, starving wetlands and mangroves of nutrients and damaging local fisheries. This will likely damage or destroy many coastal ecosystems such as mangroves and salt marshes, which are essential for maintaining wild fish stocks, as well as supplying seed to aquaculture. The United Nations Environment Program (UNEP), as cited by The WorldFish Center (2007), estimates the annual ecosystem value of mangroves at USD 200,000 - USD 900,000 per square kilometer.

- Distributional shift in fish and invertebrate species, fall in fisheries catch potential at low latitudes (IPPC, 2014b). Fisheries yield is projected to increase by $30-70 \%$ in high latitudes, but to fall by $40-60 \%$ in the tropics and Antarctica, based on $2^{\circ} \mathrm{C}$ warming (Holmyard, 2014). For example, the North Sea herring fishery collapsed in 1977 and was closed for 5 years. Bailey and Steele mentioned that although the rapid recovery of the resource surprised fisheries biologists, the most dramatic effect on the industry resulted from a permanent change of consumer preferences away from kippers and fresh and pickled herring (as cited in IPPC, 2001). The fishery recovered, but the market did not.

- As climate change is projected to affect both the quantity and quality of marine fish caught by fleets as well as the distribution or allocation of resources within and between

Table 3. World fish and fishery products trade

\begin{tabular}{|c|c|c|c|c|c|}
\hline \multicolumn{6}{|c|}{ Comodity Trade and Production: Quantity (t) } \\
\hline Trade flow & Comodity & 2010 & 2011 & 2012 & 2013 \\
\hline \multirow{4}{*}{ Export } & Crustaceans & 3425803 & 3478496 & 3188605 & 3203039 \\
\hline & Fish & 23078685 & 23696286 & 24559588 & 25164790 \\
\hline & Fish, crustaceans, molluscs and other aquatic invertebrates & 4982700 & 5118931 & 5525498 & 4867943 \\
\hline & Molluscs, aquatic invertebrates & 2850500 & 3069647 & 3062088 & 3174825 \\
\hline \multicolumn{2}{|l|}{ Total Export } & 34337688 & 35363360 & 36335779 & 36410597 \\
\hline \multicolumn{6}{|c|}{ Comodity Trade and Production: Value (USD 000) } \\
\hline Trade flow & Comodity & 2010 & 2011 & 2012 & 2013 \\
\hline \multirow{4}{*}{ Export } & Crustaceans & 22840913 & 26994215 & 26361202 & 29674363 \\
\hline & Fish & 70385629 & 81660201 & 82234125 & 87151820 \\
\hline & Fish, crustaceans, molluscs and other aquatic invertebrates & 6884069 & 7535489 & 7928233 & 7953524 \\
\hline & Molluscs, aquatic invertebrates & 11313025 & 14240682 & 13855626 & 14320850 \\
\hline Total Export & & 111423636 & 130430587 & 130379186 & 139100557 \\
\hline
\end{tabular}

Source: FAO - Fisheries and Aquaculture Information and Statistics Branch - Downloaded from http://www.fao.org/fishery/statistics/ on $2016 / 03 / 23$. 
nations' Exclusive Economic Zones (EEZs), the economics of fishing will also be significantly affected (Pinnegar, 2012).

- During the process of adapting to the changes in fish stocks and ecosystems, the cost of fishing operations may temporarily increase. For example, Garza-Gil et al. stated that earnings in the European sardine fishery were estimated to decrease by up to $1.4 \%$ on average per year with rising temperatures (2010). In addition, changes in migratory routes and fish distribution would affect travel time which can lead to significant increases or decreases in fuel costs and the cost of ice. A study by Abernethy et al. cited in Pinnegar (2012) demonstrated that fuel costs can be a very important determinant of fleet behaviour, with fishing vessels tending to operate closer to port when fuel costs are high. Tidd et al. argued that this suggests that 'adaptive capacity' may be limited in some fleets and it is possible that some fishermen may choose to leave the industry rather than follow their traditional target species northwards (as cited in Pinnegar, 2012).

- Distribution changes may have significant consequences for the distance that must be travelled by fishing boats to reach the target resources with implications for fuel usage and time at sea. In addition, increased or reduced storminess could impact the ability of fishing boats to access resources in the future, which may be further constrained if a 'days at sea' based management regime is in place. For example, the North Sea cod fishing industry now relies on only 1 or 2-year classes (Cook and Heath, 2005) and therefore is vulnerable to a year or two of poor recruitment caused by adverse climatic conditions.

- Recruitment is also strongly affected by climate variability (Walther et al., 2002) and some stocks may become vulnerable to overfishing at levels of fishing effort that had previously been sustainable (Easterling et al., 2007). Many capture fisheries worldwide have declined sharply in recent decades or have already collapsed from overfishing, and major fishing grounds are concentrated in zones threatened by pollution, the mismanagement of freshwater and habitat and coastal zone modification. Currently, slightly less than 30 percent of the wild fish stocks regularly monitored by FAO are overfished (Ababouch, 2014). Just over 70 percent are being fished within biologically sustainable levels. Of the stocks assessed, fully fished stocks accounted for over 60 percent and underfished stocks about 10 percent.

The type and intensity of the listed potential impacts reflect a combination of three key factors: the exposure of a particular system to climate change, the degree of sensitivity to climate impacts and the adaptive capacity of the group or society experiencing those impacts. The WorldFish Center (2009) argues that vulnerability varies greatly across production systems, households, communities, nations and regions. In relation to the above, one can assume that small-scale fishers and fish-farmers have contributed little to the causes of climate changes but will be amongst the first to feel their impacts.

Some anticipated consequences of climate changes in fish production systems already highlighted include risk from extreme events (like hurricanes) and occupational change in areas such as markets, distribution and processing. Furthermore, the increasing scarcity of the resources amplifies the competition for resource access, potentially a source of conflicts between operators (caused by falling productivity, species migration and localized extinctions). More competition can lead to conflict between ocean users themselves, and to tensions that spill over to include other stakeholders and the general public (McGrath, 2004). Conflicts over the use of marine and coastal space tend to fall into two broad categories (Sørensen et al., 2003). The first category concerns areas with existing regulated, restricted or prohibited access such as: major shipping routes, military exercise grounds, major structures, sub-sea cables or pipelines, and marine protected areas for fisheries management or marine conservation. The second one refers to areas with conflicting uses such as: commercial and recreational fishing grounds, resource extraction areas, tourism and non-consumptive recreational areas, archaeological sites such as shipwrecks, and those with cultural significance.

\section{CONTRIBUTING TO MITIGATION: WHAT CAN BE DONE BY FISHING-RELATED ACTIVITIES?}

Inertia toward continued emissions creates potential 21stcentury global warming that is comparable in magnitude to that of the largest global changes in the past 65 million years but is orders of magnitude more rapid (Diffenbaugh and Field, 2013). Mora et al. (2013) stress the urgency of mitigating greenhouse gas emissions if climates potentially harmful to biodiversity and society are to be prevented.

According to Cochrane et al. (2009), fishing activities contribute to emissions of greenhouse gases (GHG) which are responsible for human-induced climate change, both during capture operations and subsequently during the transport, processing and storage of fish. However, those impacts are small when compared with other sectors. Tyedmers et al. (as cited in The WorldFish Center, 2009) argue that fishing burns $1.2 \%$ of the fossil fuel used globally each year. While the potential benefit of investing in fishing energy efficiency and emission reduction is minor, the sector does provide other opportunities to improve livelihoods and environmental and resource management in ways that mitigate climate change. In many instances, climate change mitigation could be complementary to and reinforce existing efforts to improve fisheries and aquaculture sustainability (e.g. reducing fishing effort and fleet capacity in order to reduce energy consumption and carbon emissions, and reducing fishmeal reliance in aquaculture). In this regard, Santos et al. (2002) point out that stocks endangered by climate change should be protected with fishing bans, increased minimum catch 
sizes, wider net sizes, etc. Mitigation strategies for fisheries include promoting the use of fuel-efficient fishing vessels and methods, removing such disincentives to energy efficiency as fuel subsidies and reducing overcapacity in global fishing fleets, though as with other food sectors, management of distribution, packaging and other supply chain components will also contribute to decreasing the sector's carbon footprint (Cochrane et al., 2009 and The WorldFish Center, 2009).

Aquaculture's expansion helps improve the diets of many people, especially in poor rural areas where the presence of essential nutrients in food is often scarce. Pillay (2004) mentions that in the overall context of the environmental impact of human activities, particularly when compared with agriculture, domestic uses, industries, development of infrastructure, the contribution of traditional aquaculture systems was unquestionably small. Many of the traditional aquaculture systems functioned as efficient means for the recycling of agricultural and domestic waste water, whereby the water released by aquaculture had, in many cases, higher quality levels compared to the recorded at entrance. Quite different from what is found nowadays in some of the industrial units, considered potential polluters and causing the degradation of wetlands. Ababouch (2014) warns that in order to continue to grow sustainably, aquaculture needs to become less dependent on wild fish for feeds and introduce greater diversity in farmed culture species and practices. Cochrane et al. (2009) argue that the sustainable use of genetic diversity, including through biotechnologies, might have positive efficiency impacts over aquaculture systems (e.g. by widening the production scope of aquaculture species with less environmental impact or allowing the use of agricultural crop materials or waste products for the growth of carnivorous aquatic species), but they would need to be evaluated with wider social, ecological and political criteria. On this matter, the promotion of organic and multitrophic aquaculture based on good environmental practices, from the way the maintenance of the breeding tanks is done to the different combinations of organisms (e.g. seaweeds and fish) and the type of feed used, is recent in the European context of an aquaculture increasingly industrialized. The option for these types of integrated production systems with high quality standards, rather than a focus on mass production, could contribute to the sustainability of the activity itself in a perspective of safeguarding the surrounding environment; the adoption of production methodologies that contribute to the minimization of the impacts on the effluent receiver systems of aquaculture activities, as is the case of recirculation systems and multitrophic systems as well as the recovery and reuse of abandoned wetland areas that are at risk of losing their role in the ecosystem due to this abandonment, are forms of conservation and management that promote sustainable aquaculture.

An estimated 1.3 billion tonnes of food are lost per year about one-third of all food produced. This figure includes post-harvest fish losses which tend to be greater in small- scale fisheries. In small-scale fisheries, quality losses are often far more significant than physical losses. Improved handling, processing and value-addition methods could address the technical aspects of this issue, but it is also vital to extend good practices, build partnerships, raise awareness and develop capacity, and relevant policies and strategies.

The seafood industry is generally dependent on fossil fuels for transport, both in fishing vessels and in carrying produce to market. For domestic and export transport, options for reducing GHG emissions include improving energy efficiency of vehicles, switching to less carbon-intensive fuels such as biofuels, fundamentally changing the energy basis (such as switching to electric vehicles), changing the mode of carriage (for example, from air to sea) and reducing the overall number of journeys (Holmyard, 2014).

According to Pinnegar (2012), the estimated total cost of adaptation for fisheries globally between 2010 and 2050 is up to USD 30 billion per year. In Europe, the estimated annual cost of adaptation lies between USD 0.03 and 0.15 billion. Adaptation to climate change is likely to involve an extension of such policies, with a focus on providing alternative sources of income in fishing communities to lessen the dependence on fishery resources.

\section{CONCLUSIONS: INCREASING THE RESILIENCE OF FISHERIES RESOURCES AND FISHING-DEPENDENT COMMUNITIES}

The adaptability of fisheries and aquaculture to the impacts of climate change, particularly in view of a possible redistribution of fisheries resources and a change of the species life cycle, can be achieved by deepening and updating the knowledge of these changes, ensuring that this knowledge comes to operators in an appropriate manner and introducing flexibility and innovation capacity in carrying out these activities, in order to allow the focus changes, tools and practices that may be necessary. Climate change may be a cause of redistribution of fishing resources and this knowledge is critical to anticipate future evolution scenarios and to prepare the fishing and aquaculture operators. Equally important is an understanding of the ways that people cope with and adapt to living in a changing climate, and how their institutions and livelihood systems have evolved to maintain resilience to future change in aquatic ecosystems.

Developing policies and strategies to address climate change impacts on fisheries and aquaculture depends on identifying vulnerable places and people, and understanding what drives their vulnerability. This requires vulnerability and risk assessment at multiple scales (national, regional and local) and taking into account multiple interacting drivers. For instance, adaptations carried out by other sectors will have impacts on fisheries, in particular inland fisheries and aquaculture (e.g. irrigation infrastructure, dams, fertilizer use runoff), and will require carefully considered trade-offs or compromises. 
Multidisciplinary and transdisciplinary problem focused approaches that combine different knowledge systems (e.g. authorities, decision-makers, local communities, science, etc.) are needed to generate novel insights into the management of multiple uses of ocean space and to compliment risk justified decision making. Imposing top-down, detailed prescriptions for "solving" collective action problems by policymakers located far from particular collective action problems has rarely been a successful strategy.

Implementing adaptation and mitigation pathways for communities dependent on fisheries, aquaculture and aquatic ecosystems will need increased attention from policy-makers and planners. Sustainable and resilient aquatic ecosystems not only benefit fishers and coastal communities but also provide goods and services at national and global levels, for example, through improved food security and conservation of biodiversity.

Research \& Development studies and gathering of knowledge that might fill the gaps still existing in climate change impacts seem critical to raise the efficiency of potential adaptation procedures. Among others, the following actions should be developed:

- study of climate change at all time scales and building climate evolution scenarios;

- study of the processes occurring in the ocean-atmosphere interface and the influence of climate change in the production of phytoplankton and zooplankton, as well as the assessment of losses / biodiversity changes, prevalence of acidification phenomena and occurrence of abnormal areas of low oxygen (or "dead zones"), among others.

Although resource-dependent communities have adapted to change throughout history, projected climate change poses multiple additional risks to fishery dependent communities that might limit the effectiveness of past adaptive strategies. Despite all the efforts to improve environmental quality of coasts and seas around the world, degradation of ocean environments has continued. As well, the lack of an integrated approach when using this shared resource has often caused conflict among economic, environmental and social objectives. Management of ocean resources in a global, sustained and integrated fashion has remained elusive, despite several international agreements and initiatives. Harrison et al. (2015) stress the fact that understanding cross-sectoral impacts is important in developing appropriate adaptation strategies to climate change, since such insight builds the capacity of decision-makers to understand the full extent of climate change vulnerability, rather than viewing single sectors in isolation. In the debate over the economic scarcity of natural resources, one significant change in recent years has been a greater focus on the ecosystem services and the resource amenities yielded by natural environments. The general conclusion extracted from Krautkraemer (2005) is that technological progress has ameliorated the scarcity of natural resource commodities, but resource amenities have become scarcer and it is unlikely that technology alone can remedy that.
Around the world in recent decades, awareness has emerged that the management and governance of the ocean, coastal zones and human activities associated with it should be addressed at an ecosystem approach of sustainable development, based on a comprehensive view, not sectoral but integrated (EMAM, 2007). This configures the core of a longterm strategy to support sustainable growth in the maritime sector as a whole in what has been recently designated as Blue Growth Strategy, understood as a coherent framework for the sustainable, integrated and socio-economically sensitive management of oceans and wetlands, focusing on capture fisheries, aquaculture, ecosystem services, trade and social protection of coastal communities.

\section{RIBARSTVO I KLIMATSKE PROMJENE: NEIZBJEŽNOST ILI PROFILAKSA? DOPRINOSI NUŽNOJ RASPRAVI}

\section{Sažetak}

Klimatske promjene predstavljaju najveći izazov ovog stoljeća zbog modifikacija koje uzrokuju u vremenu i uvjetima okoline, pritom višestruko utječući na društvenu i ekonomsku dinamiku. Buduçi da su svi beskralježnjaci i ribe koji se koriste za ljudsku prehranu poikilotermni organizmi, vrlo su osjetljivi na promjene okoliša, odnosno promjenu temperature i razine kisika. Pojave kao što su porast temperature, zakiseljavanje, stratifikacija oceana i promjene slanosti već su vidljive i podložne uzrokovanju teških posljedica u vodenim ekosustavima. Moguće posljedice su pad produktivnosti, migracija vrsta i lokalna izumiranja, kao i sukob zbog uporabe ograničenih resursa te povećani rizik zbog ekstremnijih klimatskih pojava. Povećanje klimatskih promjena opravdava fokusiranje na sastavljanje i promociju strategija u svrhu kontrole inherentnog rizika i povećanja otpornosti morskih i slatkovodnih sustava koji snažno utječu na egzistenciju milijuna ljudi širom svijeta. Multidimenzionalni i cjelovit koncept za održivo upravljanje pomorskim i morskim resursima je nerazdvojiv od jasnog dokaza klimatskih promjena. Podizanje svijesti javnosti u cjelini i dionika oceana o važnosti ove teme je ključna dimenzija ovog rada.

Ključne riječi: klimatske promjene, utjecaji, ribarstvo i akvakultura, zaštita okoliša, sanacije i adaptacija, otpornost

\section{REFERENCES}

Ababouch, L. (Supvn.) (2014): The State of World Fisheries and Aquaculture Opportunities and Challenges 2014 (Supvn.). FAO Fisheries and Aquaculture Department: Rome, Italy.

Abernethy, K., Trebilcock, P., Kebede, B., Allison, E., Dulvy, N. (2010): Fuelling the decline in UK fishing communities? ICES Journal of Marine Science, 67, 1076-1085.

Bailey, R., Steele, J. (1992): North Sea herring fluctuations. In: Glantz M. H., (Ed). Climate Change, Climate Variability and 
Fisheries. Cambridge, UK: Cambridge University Press, $\mathrm{p}$. 213-230.

Burke, M., Hsiang, S., Miguel, E. (2015): Global non-linear effect of temperature on economic production. Nature, 527 , 235-239.

Cheung, W., Lam, V., Sarmiento, J., Kearney, K., Watson, R., Pauly, D. (2009): Projecting global marine biodiversity impacts under climate change scenarios. Fish and Fisheries, 10, 235-251.

Cheung, W., Lam, V., Sarmiento, J., Kearney, K., Watson, R., Zeller, D., Pauly, D. (2010): Large-scale redistribution of maximum fisheries catch potential in the global ocean under climate change. Global Change Biology, 16, 24-35.

Christensen, J., Hewitson, B., Busuioc, A., Chen, A., Gao, X., Held, I., Jones, R., Kolli, R., Kwon, W.-T., Laprise, R., Magaña Rueda, V., Mearns, L., Menéndez, C., Räisänen, J.; Rinke, A., Sarr, A., Whetton, P. (2007): Regional climate projections. In: Solomon, S., D. Qin, M. Manning, Z. Chen, M. Marquis, K.B. Averyt, M. Tignor and H. L. Miller (Eds). Climate change 2007: the physical science basis. Contribution of Working Group I to the Fourth Assessment Report of the Intergovernmental Panel on Climate Change. Cambridge, UK and New York, USA, Cambridge University Press.

Cochrane, K., De Young, C., Soto, D., Bahri, T. (Eds.) (2009): Climate change implications for fisheries and aquaculture: Overview of current scientific knowledge. FAO Fisheries and Aquaculture Technical Paper 530. FAO: Rome, Italy.

Cook, R., Heath, M. (2005): The implications of warming climate for the management of North Sea demersal fisheries. ICES Journal of Marine Science, 62, 1322-1326.

Diffenbaugh, N., Field, C. (2013): Changes in Ecologically Critical Terrestrial Climate Conditions. Science, 341(6145), 486492.

EMAM - Portuguese Mission Structure for Sea Affairs (2007): Sea National Strategy (in Portuguese). Portuguese Ministry of National Defence: Lisboa, Portugal.

Easterling, W., Aggarwal, P. (Coord. Lead Authors) (2007): Food, fibre and forest products. In: M. Parry, O. Canziani, J. Palutikof, P. van der Linden, C. Hanson (Eds.), Climate Change 2007: Impacts, Adaptation and Vulnerability. Contribution of Working Group II to the Fourth Assessment Report of the Intergovernmental Panel on Climate Change. Cambridge University Press: Cambridge, UK, p. 273-313.

Fabry, V., Seibel, B., Feely, R., Orr, J. (2008): Impacts of ocean acidification on marine fauna and ecosystem processes. ICES Journal of Marine Science, 65, 414-432.

Garza-Gil, M., Torralba-Cano J., Varela-Lafuente, M. (2010): Evaluating the economic effects of climate change on the European sardine fishery. Regional Environmental Change, 11, 1, 87-95.

Hanna, E., Cropper, T., Jones, P., Scaife, A., Allan, R. (2015): Recent seasonal asymmetric changes in the NAO (a marked summer decline and increased winter variability) and associated changes in the $\mathrm{AO}$ and Greenland Blocking Index. International Journal of Climatology, 35, 9, 2540-2554.
Harrison, P., Dunford, R., Savin, C., Rounsevell, M., Holman, I., Kebede, A., Stuch, B. (2015): Cross-sectoral impacts of climate change and socio-economic change for multiple, European land- and water-based sectors. Climatic Change, 128, 3, 279-292.

Holmyard, N. (2014): Climate Change: Implications for fisheries \& aquaculture: Key Findings from the Intergovernmental Panel on Climate Change - Fifth Assessment Report. Available on URL: http://www.cisl.cam.ac.uk/business-action/ low-carbon-transformation/ipcc-briefings/fisheries-andaquaculture.

IFAD International Fund for Agricultural Development (2008): Climate Change: A Development Challenge. Available on URL: http://www.ifad.org/climate/cop18.htm.

IPCC Intergovernmental Panel on Climate Change (2001): Climate Change 2001: Synthesis Report. A Contribution of Working Groups I, II and III to the Third Assessment Report of the Intergovernmental Panel on Climate Change. Cambridge University Press, Cambridge, UK, $148 \mathrm{pp}$.

IPCC (2007a): Climate Change 2007: Synthesis Report - Contribution of Working Groups I, II, and III to the Fourth Intergovernmental Panel on Climate Change. [Core Writing Team: R. Pauchauri and A. Reisinger (eds.)]. IPCC: Geneva, Switzerland, p. 1-8.

IPCC (2007b): Summary for policymakers. In: S. Solomon, D. Qin, M. Manning et al. (Eds.), Climate Change 2007: The Physical Science Basis. Contribution of the Working Group I to the Fourth Assessment Report of the Intergovernmental Panel on Climate Change. Cambridge University Press: Cambridge, UK, p. 1-22.

IPCC (2014a): Climate Change 2014: Synthesis Report. Contribution of Working Groups I, II and III to the Fifth Assessment Report of the Intergovernmental Panel on Climate Change [Core Writing Team, R.K. Pachauri and L.A. Meyer (eds.)]. IPCC, Geneva, Switzerland, 151 pp.

IPCC (2014b): Climate Change 2014: Impacts, Adaptation, and Vulnerability. Part A: Global and Sectoral Aspects. Contribution of Working Group II to the Fifth Assessment Report of the Intergovernmental Panel on Climate Change [Field, C.B., Barros, V.R., Dokken, D.J., Mach, K.J., Mastrandrea, M.D., Bilir, T.E., Chatterjee, M., Ebi, K.L., Estrada, Y.O., Genova, R.C., Girma, B., Kissel, E.S., Levy, A.N., MacCracken, S., Mastrandrea, P.R., White, L.L. (eds.)]. Cambridge University Press, Cambridge, United Kingdom and New York, NY, USA, 1132 pp.

Krautkraemer, J. (2005): Economics of Natural Resource Scarcity: The State of the Debate. Discussion Paper 05-14 Resources for the Future, 4-45.

Lan, K., Lee, M., Zhang, C., Wang, P., Wu, L., Lee, K. (2014): Effects of climate variability and climate change on the fishing conditions for grey mullet (Mugil cephalus L.) in the Taiwan Strait. Climatic Change, 126, 1, 189-202.

Marciano, C., Lackmann, G., Robinson, W. (2015): Changes in U.S. East Coast Cyclone Dynamics with Climate Change. Journal of Climate, 28, 2, 468-484. 
McGrath, K. (2004): The Feasibility of Using Zoning to Reduce Conflicts in the Exclusive Economic Zone. Buffalo Environmental Law Journal, 11, 183-213.

Meehl, G., Stocker, T., Collins, W., Friedlingstein, P., Gaye, A., Gregory, J., Kitoh, A., Knutti, R., Murphy, J., Noda, A., Raper, S., Watterson, I., Weaver, A., Zhao, Z. C. (2007): Global climate projections. In: Solomon, S., D. Qin, M. Manning, Z. Chen, M. Marquis, K.B. Averyt, M. Tignor, H.L. Miller (Eds). Climate change 2007: the physical science basis. Contribution of working group I to the Fourth Assessment Report of the Intergovernmental Panel on Climate Change. Cambridge, United Kingdom and New York, USA. Cambridge University Press.

Mora, C., Frazier, A., Longman, R., Dacks, R., Walton, M., Tong, E., Sanchez, J., Kaiser, L., Stender, Y., Anderson, J., Ambrosino, C., Fernandez-Silva, I., Giuseffi, L., Giambelluca, T. (2013): The projected timing of climate departure from recent variability. Nature, 502, 183-187

Nicholls, R., Wong, P. (Coord. Lead Authors) (2007): Coastal systems and low-lying areas. In: M. Parry, O. Canziani, J. Palutikof, P. van der Linden and C.E. Hanson (Eds.), Climate Change 2007: Impacts, Adaptation and Vulnerability. Contribution of Working Group II to the Fourth Assessment Report of the Intergovernmental Panel on Climate Change. Cambridge University Press: Cambridge, UK, pp. 315-356. Available on URL: https://www.ipcc.ch/pdf/assessmentreport/ar4/wg2/ar4-wg2-chapter6.pdf.

Otto-Bliesner, B., Brady, E., Fasullo, J., Jahn, A., Landrum, L., Stevenson, S., Rosenbloom, N., Mai, A., Strand, G. (2015): Climate Variability and Change since 850 C.E.: An Ensemble Approach with the Community Earth System Model (CESM). Bulletin of the American Meteorological Society (in press).

Pillay, T. (2004): Aquaculture and the Environment, 2nd ed.; Blackwell Publishing, Ltd.: Oxford, UK.

Palmer, G., Hill, J., Brereton, T., Brooks, D., Chapman, J., Fox, R., Oliver, T., Thomas, C. (2015): Individualistic sensitivities and exposure to climate change explain variation in species' distribution and abundance changes. Science Advances 1(9). Downloaded from http://advances.sciencemag.org/ on March 28, 2016.

Parmesan, C., Yohe, G. (2003): A globally coherent fingerprint of climate change impacts across natural systems. Nature, 421, 37-42.

Pinnegar, J. (2012): Climate change and European fisheries: observed changes and future prospects. EFARO Position Paper. Based on the outcome of the EFARO Climate Change Workshop, held in 14-15 March 2011, Amsterdam.

Pinsky, M., Worm, B., Fogarty, M., Sarmiento, J., Levin, S. (2013): Marine Taxa Track Local Climate Velocities. Science, 341, 1239-1242.

Santos, A., Borger, M., Groom, S. (2001): Sardine and horse mackerel recruitment and upwelling off Portugal. ICES
Journal of Marine Science, 58, 589-596.

Santos, F., Forbes, K., Moita, R. (2002): Climate Change in Portugal. Scenarios, Impacts and Adaptation Measures SIAM Project. Gradiva, Lisboa.

Sarmiento, J., Slater, R., Barber, R., Bopp, L., Doney, S., Hirst, A., Kleypas, J., Matear, R., Mikolajewicz, U., Monfray, P., Soldatov, V., Spall, S., Stouffer, R. (2004): Response of ocean ecosystems to climate warming. Global Biogeoch. Cycles, 18, $23 \mathrm{pp}$.

Sherwood, S., Bony, S., Boucher, O., Bretherton, C., Forster, P., Gregory, J., Stevens, B. (2015): Adjustments in the ForcingFeedback Framework for Understanding Climate Change. Bulletin of the American Meteorological Society, 96, 2, 217 228.

Sørensen, H., Hansen, L., Hansen, R., Hammarlund, K., Thorpe, T., McCullen, P. (2003): Social Planning and Environmental Impact WaveNet (Results from the Work of the European Thematic Network on Wave Energy), p.305-377.

Sousa Reis, C., Lemos, R., Dornelas, M., Santos, R. (2001): Fisheries. In: F. D. Santos, K. Forbes and R. Moita (Eds.), Climate Change in Portugal: Scenarios, Impacts and Adaptation Measures, pp. 415-452. SIAM Project, Gravida Publications, Lisbon, Portugal, $454 \mathrm{pp}$.

Sydeman, W., Poloczanska, E., Reed, T., Thompson, S. (2015): Climate change and marine vertebrates. Science, 13, 772777.

The World Fish Center (2007): The threat to fisheries and aquaculture from climate change. WorldFish Center: Penang. Available on URL: http://pubs.iclarm.net/resource_ centre/ClimateChange2.pdf.

The World Fish Center (2009): Climate Change: Research to Meet the Challenges Facing Fisheries and Aquaculture. WorldFish Center: Penang. Available on URL: http://pubs. iclarm.net/resource_centre/WF_2167.pdf.

Tidd, A., Hutton, T., Kell, L., Padda, G. (2011): Exit and entry of fishing vessels: an evaluation of factors affecting investment decisions in the North Sea English beam trawl fleet. ICES Journal of Marine Science, 68, 961-971.

Toresen, R., Østvedt, O. (2000): Variation in abundance of Norwegian spring-spawning herring (Clupea harengus, Clupeidae) throughout the $20^{\text {th }}$ century and the influence of climatic fluctuations. Fish and Fisheries, 1, 231 - 256.

Tyedmers, P., Watson, R., Pauly, D. (2005): Fueling global fishing fleets. Ambio, 34, 635-638.

Urban, M. (2015). Accelerating extinction risk from climate change. Science, 348(6234), 571-573.

Walther, G., Post, E. Convey, P., Menzel, A., Parmesank, C., Beebee, T., Fromentin, J., Hoegh-Guldberg, O., Bairlein, F. (2002): Ecological responses to recent climate change. Nature 416, pp. 389-395. Available on URL: http://eebweb. arizona.edu/courses/ecol206/walther\%20et\%20al\%20 nature\%202002.pdf. 